\title{
Fulfillment of the Rights of Children with Disabilities through the Involvement of Civil Society Organizations, Case of Yayasan Sayap Ibu
}

\author{
Uliviana Restu Handaningtyas \\ Communication Department, Universitas Sultan Ageng Tirtayasa \\ ulivianarestu@gmail.com
}

Ika Arinia Indriyany

Government Department, Universitas Sultan Ageng Tirtayasa

ika.arinia@untirta.ac.id

\section{Lily Ismalia}

Government Department, Universitas Sultan Ageng Tirtayasa lilyismaliaaaa@gmail.com

\section{E-ISSN 2721-0642}

\section{Article Info}

Recieved:

June 142021

Revised:

July 282021

Accepted:

August 82021

Doi Number

https://doi.org/10.37950/ijd.v3i2.106

\begin{abstract}
The rights of children with disabilities are still an unfinished discourse. In the big cities and remotes areas in Indonesia, sometimes we can hear cases of neglecting children with disabilities. The Indonesian government carries out various programs to eradicate cases of child neglect; one of the efforts taken is to permit social foundations that have special orphanages for children with disabilities to implement a legal adoption system. The question that then arises is, is the system sufficient to fulfill the rights of children with disabilities as mandated by Law No. 23 of 2002 on Child Protection? What components of rights were then successfully fulfilled through this adoption system, and what are the next steps for the government. This study seeks to provide an overview of how the adoption system fulfills children's rights with disabilities. This study using a qualitative method with a case study approach, the study's results photograph the reality experienced by foster children through the adoption system. The study results show that several main components as part of children's rights: the right to life, the right to grow without discrimination, the right to express opinions, and the right to get the best. Thus, from the results of this study, further research is needed to examine how the adoption system can be applied more effectively to reach the fulfillment of the rights of children with disabilities more optimally.
\end{abstract}

Keywords Rights of children with disabilities, adoption system, social foundations for children with disabilities 


\section{Abstrak}

Hak anak disabilitas masih menjadi wacana yang belum selesai. Kasus penelataran anak disabilitas masih terdengar baik di kota besar maupun di pelosok daerah di Indonesia. Pemerintah Indonesia melaksanakan beragam program untuk mengentaskan kasus penelantaran anak, salah satu upaya yang di tempuh adalah dengan memberikan ijin bagi yayasan sosial yang memiliki panti asuhan khusus anak disabilitas untuk menerapkan sistem adopsi secara legal. Pertanyaan yang kemudian timbul adalah, apakah sistem tersebut cukup untuk memenuhi hak anak disabilitas sebagaimana diamatkan oleh Undang-undang no 23 tahun 2002 tentang Perlindungan Anak? komponen hak apa sajakah yang kemudian berhasil dipenuhi melalui sistem adopsi ini dan bagaimana langkah pemerintah selanjutnya. Penelitian ini berusaha untuk memberikan gambaran mengenai bagaimana sistem adopsi memenuhi hak anak disabilitas. Menggunakan metode kualitatif dengan pendekatan studi kasus, hasil penelitian memotret realitas yang di alami oleh anak asuh melalui sistem adopsi tersebut. Hasil penelitian memperlihatkan beberapa komponen utama yang terpenuhi sebagai bagian dari hak anak, yaitu: hak hidup, hak tumbuh tanpa diskriminasi, hak menyampaikan pendapat, dan hak memperoleh yang terbaik. Dengan demikian, dari hasil penelitian ini dibutuhkan penelitian lanjutan untuk menelaah bagaimana sistem adopsi dapat diterapkan lebih efektif untuk menjangkau peneuhan hak anak disabilitas dengan lebih optimal.

Kata kunci : hak anak disabilitas, sistem adopsi, yayasan anak disabilitas

\section{Introduction}

Violence against children has become a central issue, especially for children with disabilities (Chan et al., 2014). This issue requires full attention by looking at the number of violence that grows every year. Indonesia recorded $73.3 \%$ of children aged 114 years experienced discipline with violence (violent discipline) and physical punishment at home. KPAI data stated 10,742 cases of violence against children committed by families and caregivers (Tanziha et al., 2020). In Indonesian households, sometimes we can find discipline with violence as a behavior related to parents' habits who emphasize physical punishment for children while every child should receive protection from the family, society, and the state. As a part of an Indonesian citizen, the government must fulfill children's fundamental rights, such as the right to life, the right to get protection to the right to be respected in social activities, and children with disabilities (Indriyany, 2015).

Law Number 23 of 2002 defines a child as not yet 18 (eighteen) years old, including a child still in the womb. Furthermore, in Article 4 of Law no. 23 of 2002, every child has the right to live, grow, develop, and participate pretty following human dignity and protection and protection from violence and discrimination. On that basis, Law Number 23 of 2002 concerning Child Protection states that children's rights are part of human rights that must be guaranteed, protected, and fulfilled by parents, families, communities, governments, and the state(Ahmed \& Nagowayousif, 2020). 
Protection for children covers all children regardless of the child's physical or mental condition. Children with special needs or often referred to as persons with disabilities, experience a different self from children in general (Currie \& Kahn, 2012). These various terms for children with special needs include exceptional (different from people in general), impairment (damaged or disabled or sick, more in medical meaning), handicap (unable to access the environment), and disability (no or lack of functionality) (Maciver \& Rutherford, 2019). The above understanding provides a view in responding to the handling of children with special needs requiring cultural and structural alignments from various parties, parents, government (Rosdianti, 2017), and community (Indriyany, 2019). Furthermore, this happens because there are still misunderstandings and discriminatory attitudes towards children with special needs who are vulnerable to violence and mistreatment.

Discrimination against children with disabilities is verbal violence and physical violence (Mantey, 2017). They were reporting from Tempo.com the chronology of children with disabilities who died due to being abused by two friends at the Pontianak City Child Service Center (Tempo, 2019). The report also stated that the family believed that their child would be okay because he was in the Children's Service Center. KPAI highlighted this situation by stating that discrimination against children with disabilities and minority children is considered normal. Indonesian seen violence as a common thing to do in educating children.

Sometimes, economic problems are considered a priority issue rather than children's rights issues, so people often reduce this issue. The struggle of children to obtain their rights is still limited to the right to education and health (often considered that children are fed enough, grow up healthy and go to school). Furthermore, the government is not considering the other rights related to children's welfare as a priority, such as obtaining legal protection, obtaining a safe and comfortable environment, the right to grow mentally healthy, and obtaining entertainment appropriate for his age. The "Child-friendly City" which once echoed became just a discourse, even just as an award label without any follow-up that "Child-friendly City" is a form of fulfilling children's rights as mandated by the law.

In this context, the fulfillment of children's rights, especially the rights of children with disabilities) need efforts to improve the adoption system. Moreover, society gives a mandate to social foundations that work in the social service to evaluate and carry out the adoption process for the children in their organizations. Among them is the Yayasan Sayap Ibu. Through the social foundation, parents can legally adopt children with special needs.

Then the discussion continues whether this step is sufficient to ensure the fulfillment of children's rights? Can the family and social environment support children's growth and development? Are the current regulations implemented by the government sufficient to address this challenge? Is this system the answer to solving the problem of fulfilling the rights of children with disabilities? 
This research attempts to provide an overview of the fulfillment of children with disabilities rights. These rights are carried out through the adoption process run by social foundations in Indonesia. Moreover, we want to know how the adoption system is a solution to problems related to the fulfillment of children's rights as mandated by the Indonesian constitution and what rights then become the main component in the adoption process as a determinant of the fulfillment of the rights of children with disabilities. This research will also highlight some of the problems that often arise during the adoption process.

\section{Theoretical Framework}

\section{Children with Disabilities}

Law Number 8 of 2016 concerning Persons with Disabilities states that disability is any person who experiences physical, intellectual, mental, and sensory limitations in the long term who is interacting with the environment can experience obstacles and difficulties to participate fully and effectively with other citizens based on equal rights. Another term for children with disabilities is called children with special needs.

Children with special needs is a term for children who experience a different self from children in general. Various terms for children with special needs include exceptional (different from people in general), impairment (damaged or disabled or sick, more in medical meaning), handicap (cannot access the environment), and disability (no or lack of functionality).

The number of people with severe disabilities in 33 provinces of Indonesia is $3,342,303$ people. Four age groups can be categorized as children according to Law no. 23 of 2002. Namely, the age group 0-4 years amounted to 17,512 people, the age group 5-9 years amounting to 54,474, the age group 10-14 years totaling 73,231 people, and the last one being the age group 15-19 years totaling 92,059 people. Suppose the total proportion of children with disabilities is 275,639 people per the year 2009. Based on the 2018 Riskesdas, 3.3\% of children aged 5-17 years have disabilities. Provinces with the highest proportion of children with disabilities are Central Sulawesi (7.0\%), North Kalimantan, and Gorontalo (5.4\%).

\section{Adoption}

Customary Law in Indonesia regulates the process of children adoption. Terms such as taking a child and adopting a child are designations of customary law resulting from adopting a child through the adoption process. The adoption of children in Indonesia through customary law varies greatly. For example, in Java, children who may be adopted are nephews themselves and cannot be outside the family of the husband and wife.

Furthermore, the adoption of a child in Java may not break the original family ties of the child. In the sense that the child enters the adoptive family and will become a member of his family but does not have his position as a biological child to continue the descendants of the adoptive parents.

Whereas in Bali, prospective adoptive parents may adopt any child, and the adopted child has the right to continue the position to continue the descendants of the adoptive parents. These regulations according to the family system adopted by 
each region. The position of this child is also regulated based on the family system, such as the patrilineal, matrilineal, parental systems. It all depending on local customs.

During the colonial period, the tradition of adopting children was widespread among Indonesian people, especially those of Chinese descent who adopted children on a large scale. For the Chinese community, adoption is a tradition and a form of worship to preserve the family's culture. Because in Chinese customs where they adhere to the male lineage system or what can be called patrilineal. The goal was to obtain a son who would preserve the family's culture and clan.

Seeing this, the Dutch East Indies government-issued regulations regarding child adoption. So finally issued Staatsblad No. 29 of 1917 contains the adoption of children that apply to the Chinese community. This regulation shows that only a husband and wife are allowed to adopt children who do not have a son, and it is permissible for a widower or widow who does not have a son to have children on the condition that they have a will from their spouse that they want a son.

The regulation also emphasized in Article 15, paragraph 2 that the adoption of a daughter is null and void. In a sense, they can only adopt boys as children. The Chinese group was included in the foreign eastern group by the Dutch East Indies government, and under Staatblad 1924 No. 557, all regulations in Burgelijk Wetboek apply to Chinese descent. So the 1917 Staatsblad Regulation No. 129 applies to the Chinese community (Musthofa, 2008)

Entering the era of independence, in 1958, the Indonesian government issued Law No. 62 of 1958 concerning Indonesian citizenship. So that in this law, regulations related to child adoption are regulated in article 2. Talking about legislation related to the implementation of adoption in Indonesia goes through a very long process. They are starting in 1974 with the Draft Law on child marriage, which in article 62 also regulates the adoption of children. Through a long process, in 2002, the Indonesian government passed the Law on Child Protection. This regulation was ratified by Law Number 23 of 2002.

\section{Law number 23 of $\mathbf{2 0 0 2}$}

Law Number 23 of 2002 on Child Protection, including:

a. Protection in the field of religion

1) Protection to worship according to his religion.

2) The state, government, society, family, parents, guardians, and social institutions guaranteed the protection of children in embracing their religion. The protection of a child in embracing his or her religion includes the development, guidance, and experience of religious teachings.

b. Protection on health :

1) The government is obliged to provide facilities and organize comprehensive health efforts for children.

2) Parents and families are responsible for maintaining children's health. If they are unable to carry out their responsibilities, then the government is obliged to fulfill them. 
3) The state, government, family, and parents are obliged to protect newborns from diseases that threaten their survival or cause disability.

4) The state, government, family, and parents are obliged to protect children from attempts to transplant their organs for other parties.

The state, government, family, and parents are obliged to protect children from acts:

1) Removal of child's organs and child's body tissue without regard to the child's health;

2) Sale and purchase of organs and body tissues of children; and

3) Health research uses children as research objects without parental permission and does not prioritize children's best interests.

c. Protection in the field of education

1) The government is obliged to provide a minimum of 9 (nine) years of primary education for all children.

2) There are equal opportunities and accessibility to children with physical and mental disabilities to obtain ordinary and extraordinary education.

3) There is special education for children who have advantages.

4) The government is responsible for providing education costs and free assistance or special services for children from underprivileged families, neglected children, and children residing in remote areas.

5) The teachers, school administrators, or friends in the school protected children with disabilities from violence in educational institutions.

d. Social protection

1) The government is obliged to carry out the maintenance and care of neglected children if the Minister of Social Affairs implements maintenance and supervision.

2) The government must seek and assist children so that children can:

- Participate;

- Freedom to express opinions and think according to their conscience and religion;

- Free to receive oral or written information following the stages of the child's age and development;

- Freedom of association and assembly;

- Free to rest to play, have fun, be creative, and create arts and culture; and

- Obtain playing facilities that meet health and safety requirements.

3) For neglected children, due to some reason, their parents neglect their obligations, the institution, family, or authorized official can apply to the court to determine the child as an abandoned child.

4) The court stipulation as intended simultaneously stimulates the child's shelter, maintenance, and care. 
e. Special protection

1) The provisions of humanitarian law ensure Special protection for children who become refugees.

2) Special protection for children who are victims of riots, victims of disasters, and children in situations of armed conflict, including:

- Fulfillment of basic needs, namely: food, clothing, housing, education, health, learning and recreation, security guarantees, and equal treatment; and

- Fulfillment of special needs for children with disabilities and children with psychosocial disorders.

3) Special protection for children in conflict with the law, children in conflict with the law, and child victims of criminal acts, including:

- Humane treatment of children following the dignity and rights of the child;

- Provision of special assistants for children from an early age;

- Provision of exceptional facilities and infrastructure;

- The imposition of appropriate sanctions in the best interests of the child;

- Continuous monitoring and recording of the development of children in conflict with the law;

- Providing guarantees to maintain relationships with parents or family; and

- Protection from identity is reporting through mass media and avoiding labeling.

4) Special protection for children who are victims of criminal acts include:

- Rehabilitation efforts, both within the institution and outside the institution;

- Efforts to protect from identity reporting through mass media and to avoid labeling;

- Provision of safety guarantees for victim-witnesses and expert sanctions, whether physical, mental, or social; and

- Providing accessibility to obtain information regarding the development of the case.

5) The provision of infrastructure and facilities ensures special protection for children from minority and isolated groups to enjoy their own culture, acknowledge and implement their religious teachings, and use their language.

6) Special protection for economically and sexually exploited children, including:

- Dissemination and socialization of the provisions of laws and regulations relating to the protection of economically and sexually exploited children; 
- Monitoring, reporting, and imposing sanctions; and

- Involvement of various government agencies, companies, trade unions, non-governmental organizations, and the community to eliminate children's economic and sexual exploitation.

7) Special protection for children who are victims of the abuse of narcotics, alcohol, psychotropics, and other addictive substances (drugs), and are involved in their production and distribution, are carried out through supervision, prevention, treatment, and rehabilitation efforts by the government and the community.

8) Government and community need to give special protection for child victims of abduction, sale, and child trafficking through supervision, protection, prevention, treatment, and rehabilitation.

9) Special protection for child victims of violence includes physical, psychological, and sexual violence through the following efforts:

- Dissemination and socialization of the provisions of laws and regulations that protect child victims of violence; and monitoring, reporting, and imposing sanctions.

10) Special protection for children with disabilities through the following efforts:

- Humane treatment of children by the dignity and rights of children;

- Fulfillment of special needs; and

- Obtaining equal treatment with other children to achieve the fullest possible social integration and individual development.

11) Special protection for child victims of abuse and neglect is carried out through supervision, prevention, treatment, and rehabilitation by the government and the community.

This theoretical framework is used to see further how the rights of children with disabilities are fulfilled during the adoption process. There is no difference between the adoption process for disabled and non-disabled children. However, it is necessary to have a disability perspective that sees further that the problems of children with disabilities are different from those of non-disabled children. For example, the challenges and obstacles to the growth and development of non-disabled children will be different from those of children with disabilities. Challenges and barriers to growth and development in children with disabilities will always be related to the problem of their disability. So each child needs to be approached and understood in a different way.

\section{Research Methodology}

This study uses a qualitative method with a case study approach (Creswell, 2016). We use this approach to obtaining a more detailed picture of the adoption process carried out by social foundations in Indonesia. The case study also allows the 
author to explore further the government's response and solutions to social foundations and local governments regarding the adoption process and the rights of children with disabilities.

There are two ways to collecting data. The first is in-depth interviews with key informants and informants directly involved in the adoption process, starting from foster parents, children with disabilities who have been adopted and do not, leaders of social foundations, and social services that act as supervisors in the adoption process. Second, through document study to clarify previously collected data and obtain a more detailed explanation of the adoption process and children's rights with disabilities.

\section{Result and Discussion}

Children need a proper place for growth and development to provide a sense of security and comfort for children to grow as independent, responsible individuals and participate in social and state life. However, there are still cases of child neglect committed by biological parents, including children with disabilities. They -the biological parents of the abusers- see disabled children as a burden that burdens their living conditions and a disgrace that must be hidden, covered up, and even thrown away. This pathetic condition is still encountered not only in big cities but also in remote areas.

One of the government's programs to protect the interests of abandoned children is the adoption program. Mrs. Rien Tjipto Winoto, Chairperson of the Yayasan Sayap Ibu Jakarta, stated: "The adoption program, this adoption is indeed a program from the Ministry of Social Affairs which is sent to children's orphanages like this Ibu Wing Foundation." The foundation then has the responsibility to ensure that the adoption process goes according to the regulations and that its foster children have a better family environment.

\section{Figure 1. The process of Child Adoption}

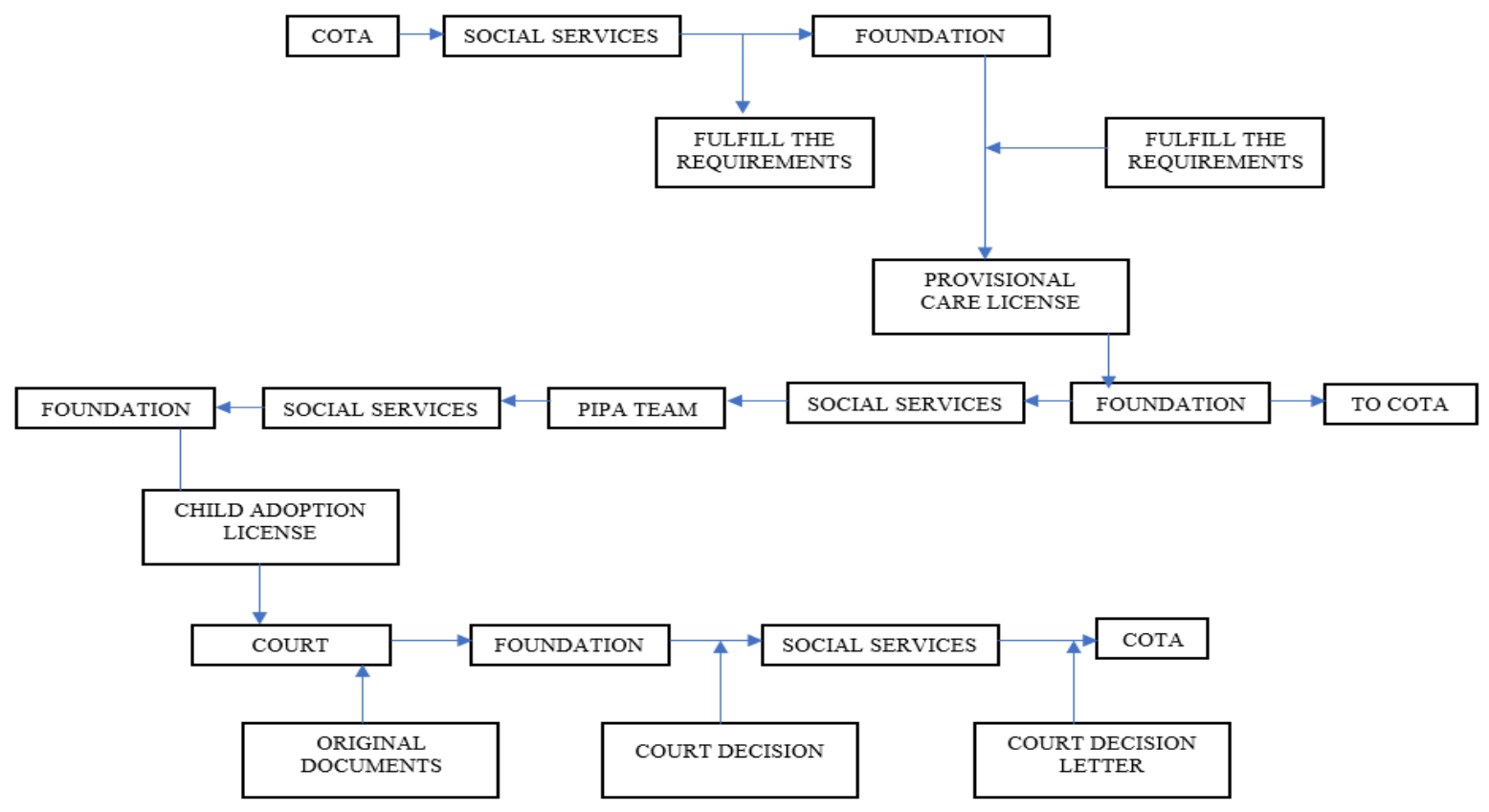


The stages in adopting a child are necessary, and this aims to ensure the achievement of the goal of adoption, namely providing protection and welfare for the child. Rien Tjipto Winoto's stated: "...that in adopting a child it is about the future of the child's life, there is a moral responsibility for us as social workers to provide protection, so related regulations like this must be firm. Many people say that adoption in Indonesia is long-winded. If not, it's a pity for our children."

The fulfillment of children's rights with disabilities through the adoption system includes several components, namely; (1) Non-discriminatory, (2) Right to life; (3) Provide the best for children; (4) Adults need to respect the opinion of their children. This component is a fundamental right that every child deserves, especially if the child has limitations. Fulfillment of children's rights is a priority that needs to be maintained. Therefore the adoption process evaluates further whether the adopted child obtains their fundamental rights or not. In some cases, foster parents feel that they have had enough to fulfill their children's rights, but on further evaluation, there are differences between children with special needs and children without special needs.

1. The right to grow without discrimination

In the adoption process, generally, the foundation will conduct background checks on prospective foster families to ensure that there are no attempts to falsify personal and family data. Then the foundation will start by getting the prospective foster family to care for children with special needs. One way is to train how to interact and communicate with children with disabilities. Through this interaction and communication, prospective foster parents are encouraged to understand what children with disabilities want using body symbols or facial expressions. This habituation is carried out repeatedly with the aim that prospective foster parents can adapt to the habits and needs of the child to be adopted and not vice versa. This activity also aims to prevent prospective foster families from making comparisons with the behavior of non-disabled children. These differences in the ways of communicating and interacting with children with disabilities can trigger feelings of discomfort in foster families, which can further lead to abusive or discriminatory behavior if there is no effort to understand and adapt to the way children with disabilities communicate. The results of the foundation's observations as long as prospective foster parents interact with prospective foster children will be an essential point in adopting children with disabilities. In this context, the foundation requires conducting in-depth observations of prospective foster parents.

2. Right to life

Concerning this right, all children with disabilities have the right to grow and develop like children. The principles are; first, children have the right to live, and second, children with disabilities have the right to get a decent life. Children with disabilities who live in orphanages managed by social foundations have various backgrounds, ranging from orphans intentionally left because of the economic inability of biological parents to raise children with disabilities to children 
whom their biological parents deliberately abandon. Through social care parenting, these disabled children can survive and grow according to their right to life. In the adoption process, one of the factors considered is the ability of the prospective foster family both in terms of economy and psychology. They require different parenting patterns and have different physical and mental needs than children without special needs. Therefore, financial support by prospective foster families. This financial support will ensure the fulfillment of the physical needs of children with disabilities who will be adopted. If they agree with the basic needs of children with disabilities, then this point becomes a supporting point in adopting a child with a disability. Financial problems are often a trigger factor for parents' abusive behavior towards children, so the foundation will try to minimize this risk by only choosing prospective foster families who are economically stable and psychologically stable.

3. The right to get the best

This point generally encourages prospective foster families to adapt to the growth patterns of children with disabilities, especially foster parents. This parenting includes ways of thinking, point of view, and commitment. The way of thinking of foster parents must follow the way of thinking of children with disabilities, especially those with specific backgrounds (victims of violence, outcasts, or victims of child sales). These children generally have difficulty in expressing what they want and think. In some instances, children with disabilities tend to be closed, and difficult to accept the presence of other people who do not know. Generally, this happens to children who are victims of violence or child trafficking. They lose the confidence and sense of security they should get from the adults around them. The pattern of parenting for children with disabilities no longer uses the point of view of thinking of non-disabled adults. Therefore understanding what children with disabilities think and understanding what they need is one of the main requirements in the adoption process.

4. The right to express opinions

This point follows point no 3, which is to prepare the best for children by understanding how to think and adapt to children's thinking patterns with disabilities. Communication barriers are a factor that often afflicts the interaction between foster parents and foster children. Therefore, in adopting children with disabilities, prospective foster parents must adapt first to prospective foster children for a certain period under the supervision of the foundation before finally applying for adoption. It is approved. This process is to help prospective foster parents build an emotional relationship with prospective foster children. With this relationship, the prospective foster children can open themselves up and share their opinions and opinions with prospective foster parents. Moreover, on the other 
hand, prospective foster parents can understand the mindset of prospective foster children and build mutual trust between the two.

The problem that then arises is in the evaluation and monitoring process. With the limited number of employees and the size of the area, they hampered the monitoring process for foster children and their foster families. Several cases had emerged, including the lack of harmony in the relationship between father and mother, which then impacted the psychological development of children with disabilities until returning children with disabilities to orphanages due to household problems of foster parents.

\section{Conclusion}

The adoption process for disabled and non-disabled children does not have a substantial difference. The difference is how foundations and prospective families must fully understand the concept of disability in order to be able to accept children with disabilities. The adoption process carried out by social foundations has included the components needed to fulfill the rights of children with disabilities. These components are observed and evaluated as part of the adaptation process and build trust between prospective foster parents, prospective foster children, and the foundation as the final decision maker. The adoption process can be seen as the right solution to ensure the welfare of children with disabilities by placing them in an economically and psychologically stable family environment. This is important to do to ensure that the rights of children with disabilities during the adoption process as well as when the child lives with adoptive parents can be fulfilled.

\section{About Authors}

Uliviana Restu Handaningtias is a lecturer from Sultan Ageng Tirtayasa University. Her research focuses cultural and gender studies.

Ika Arinia Indriyany is a lecturer from Government Studies, Sultan Ageng Tirtayasa University. Her research interest is the fulfillment of rights, especially on women and persons with disabilities.

Lily Ismalia is student in Sultan Ageng Tirtayasa who completed reasearch on Yayasan Sayap Ibu Jakarta

\section{Acknowledgments}

Thank you to all those who have helped in the completion of this research.

\section{References}

Ahmed, O. S., \& Nagowayousif. (2020). The role of child welfare organizations in the social protection of children. Journal of Critical Reviews, 7(6), 860-864. 
https://doi.org/10.31838/jcr.07.06.148

Chan, K. L., Emery, C. R., \& Ip, P. (2014). Children With Disability Are More at Risk of Violence Victimization: Evidence From a Study of School-Aged Chinese Children. 31(6). https://doi.org/https:// doi.org/10.1177/0886260514564066

Creswell, J. (2016). Reaserch Design, pendekaan metode kualitatif, kuantitatif, dan campuran (4th ed.). PUSTAKA PELAJAR.

Currie, J., \& Kahn, R. (2012). Children with Disabilities: Introducing the Issue. The Future

https://futureofchildren.princeton.edu/sites/futureofchildren/files/media/childr en_with_disabilities_22_01_fulljournal.pdf

Indriyany, I. A. (2015). Pelayanan Publik dan Pemenuhan Hak Difabe: Studi tentang Layanan Pendidikan Inklusif Melalui Kasus Pemindahan Difabel dari Sekolah Reguler ke Sekolah Luar Biasa di Yogyakarta. Inklusi, 2(1), 1. https://doi.org/10.14421/ijds.020109

Indriyany, I. A. (2019). Dinamika Non-Government Organization: Studi Kasus Kontestasi dan Kompromi Semu NGO Difabel di Yogyakarta. Jurnal Polinter, 4(2). https://doi.org/http://dx.doi.org/10.21776/ub.IJDS.2017.004.01.10

Maciver, D., \& Rutherford. (2019). Participation of Children with Disabilities in School: A Realist Systematic Review of Psychosocial and Environmental Factors. PLOS Digital Health. https://doi.org/https://doi.org/10.1371/journal.pone.0210511

Mantey, E. E. (2017). Discrimination Against Children with Disabilities in Mainstream Schools in Southern Ghana: Challenges and Perspectives from Stakeholders. International Journal of Educational Development, 54. https://doi.org/https://doi.org/10.1016/j.ijedudev.2017.02.001

Musthofa, M. (2008). Pengangkatan Anak Kewenangan Pengadilan Agama. Kencana Prenada Media Group.

Rosdianti, Y. (2017). Meaningful Work and Disability: a Dignity Towards Social Inclusion. Indonesian Journal of Disability Studies, 4(1), 77-94. https://doi.org/http://dx.doi.org/10.21776/ub.IJDS.2017.004.01.10

Tanziha, I., Utomo, H., Mu' adofatunnisa, I. A., Fitriani, N., \& Lukitasari, I. (2020). Profil Anak Indonesia 2020. Kementerian Pemberdayaan Perempuan dan Perlindungan Anak.

Tempo. (2019). Anak Difabel di Pontianak Dianiaya Temannya, Pamit Beli Bakso. https://m.difabel.tempo.co/amp/1230605/anak-difabel-di-pontianak-dianiayatemannya-pamit-beli-bakso 